\title{
Effect of social media on post graduate students during academic lectures and library session. A case study of Salford University Manchester, United Kingdom
}

\author{
Akubugwo, Ijeoma $\mathrm{G}^{1}$ and Maria Burke ${ }^{2}$ \\ ${ }^{1}$ E-library unit, Abia State University main library, Uturu,Nigeria. \\ ${ }^{2}$ Department of Information Technology, Salford University, United Kingdom.
}

\begin{abstract}
The present study examined attitude to and extent of usage of social media by post graduate students at Salford University during Academic Lectures and Library Session. Data collection involved both qualitative and quantitative methodology involving oral interview and questionnaire administration. Likert model was employed in response to eighteen -item questionnaire which were physically administered to 120 randomly selected post graduate students who have social media accounts. Another six students were interviewed face to face differently and their responses were recorded. The data obtained was analyzed using statistical package for social sciences (SPSS). The results showed that many students use social media especially Facebook, myspace, and Twiter during academic classes. Findings of this study also suggest that social media could negatively impact on the students' academic progress and that timed-off software should be installed in the classes.
\end{abstract}

Key words: qualitative, quantitative, social media, questionnaire.

\section{Introduction}

The Internet started as far back as 1969, and then known as ARPANET; it was originated and developed by ARPA (Advanced Research Project Agency) that operated with the US Defence Department, [1]. The aim of ARPANET was to establish communication amongst military agencies and store huge amount of important data/information as regards the nuclear holocaust. The aim was to ensure that the defence communication network survived any nuclear attack. This was successfully achieved through the use of a network that allowed data to pass through multiple ways from the data source to data destination, [2]. According to Comer [3] assuming the network got destroyed; there would be full communication through other paths. This is the origin of the Internet. The internet comprises millions of interconnected computers and has the greatest information storage globally. It is very difficult to calculate users of the internet in the whole world and come out with an exact figure, but it is possible to give an estimate of number of users.

Three types of social media will be briefly discussed below by the researcher in this study as follows:

MySpace

MySpace is one of the more popular social media networks that were launched in California in 2003 to compete with other networks like Friendster, Xanga etc., [4]. It grew very rapidly by taking advantage of Friendster's mistake and failure. According to [4] Indie-rock bands that were expelled from Friendster because of profile problems; they joined MySpace network and began to attract profiles. There were numerous advertisements by popular clubs in this network. Anderson said that it is believed that music was not the key issue that attracted people to MySpace rather there was a symbiotic association between music bands and fans that helped to expand MySpace beyond expectation.

MySpace is unique because it is continuously adding features based on the users interest or demand [5]. Boyd [5] said that teenagers started using MySpace in 2004 to connect to their friends and not just for the reason that they belong to the bands. MySpace site achieved its highest growth rates with three different groups, namely, the musicians, teenagers and undergraduates. MySpace was purchased by News Corporation for \$580million, which attracted enormous media attention.

\section{Twitter}

Twitter was introduced in 2006. The twitter co-founder was amazed at the type of success it has recorded. Twitter is one of the social media web tools in which the users normally post short and simple messages known as tweet in not more than 140 words. Some people tweet with micro-blog platform, while others regard it as a social networking site [6]. Web services that allow people to post brief messages to other users of the same service are micro-blogging. It derived its feature from Instant Relay Chat (IRC) including instant messaging and handsets. According to Bake [6], Twitter is one of the social media web-based applications that allow its users to build their own profile either publicly or semi-publicly. Twitter uses the exact basic features like find people profile, picture uploading profile etc. as other social media. The traditional 
contacts in twitter are followers and following categories. Twitter does not belong to only SNSs socializing category but also to networking with navigation [7].

\section{Facebook}

Facebook was introduced in early 2004 as a social network site just for Harvard students [8]. By 2005 Facebook allowed students from other schools to register as users and eventually everybody [9]. Facebook growth has been rapid to the extent that it now has over 22 Million unique strangers with above 15 billion viewed pages.

Facebook is one of the world's most populated social media networks with no less than 400Million users [9]. Students and teenagers constitute a majority of the users, with posting of more than 1 Million posts such as pictures, chats and messages on daily basis. Mark Zuckerberg is the founder of this site who said that if Facebook were to be a country, it would have been the eighth most populated country in the world [9]. Researchers are still investigating the reason why Facebook attracts the attention it does, especially from among the youths/ students. It is reported that students use Facebook practically on daily basis,[10]. Students post contents on Facebook and also spend much time observing the contents posted by their friends.

Table 1: Facebook statistics analysis

\begin{tabular}{|l|l|}
\hline Actions & Explanation \\
\hline Incumbent active customers/user I Facebook & Above 500 Million \\
\hline Users that keep updating their status daily & Above 35 Million \\
\hline Uploaded picture monthly & Above 3 Billion \\
\hline Events generated monthly & Above 3.5 Million \\
\hline The pages created by fans & Above 5.3 billion \\
\hline Every day login on Facebook & $50 \%$ dynamic users/customers \\
\hline Monthly shared contents & Above 30 billions \\
\hline People that use Facebook through phone & Above 250 Million \\
\hline Every day fans on Facebook & Above 20 million \\
\hline
\end{tabular}

Source: Facebook.com/press, [11].

\section{Social media network and students}

Students have integrated part of their life style with social networks. Social media have virtually turned to communal set up where students/youths interact and share information, store and keep their relationships updated, on daily basis, which constant use is thought to affect their academic work, [12]. There is however, a rapid increase also in the use of internet technology for relevant academic and classroom processes by both the teachers and their students, $[13,14,15]$. Students in higher institutions adopt different types of social media communication as the utmost medium to interact, keep in touch or relate with their family and friends [16]. According to Flad,[16] social media sites like Facebook and MySpace are among the more popular sites that students mostly spend their time in.

According to Atwong and Hugstad [13,17], the internet technology enhances and improves learning and expertise, provides updated learning materials, affords universal perspective including strong, business connection, enhanced job- market skills such as communication, team leadership and team-building.

According to Rosen [18], children born in the 1980s and 1990s who are the present day students are described as "Welcome to the Net Generation". The researcher said that the majority of these students spend their time, swimming in the ocean of "social media diet", accumulating jobs with the overtime, enjoying different types of entertainment, social interaction with all sorts of electronic media technology. Veen and Vrakking [19] also called these youths/students "Homo Zappiens" because they are the first people to test any new released technology, and they were born in the pull of technology with yearly technology advancement, enjoying social media where they text more than they discuss on phone.

It is assumed that all these technology advancement will create a favourable impact on these students' academic work or learning settings but most empirical research carried out showed that these students do not have the skills. Moreover, it is now thought that there are negative effects of social media as regards amount of time spent on their academics. Students are now specialists in multitasking, Homo Zappiens carrying out their home tasks such as Twitting, YouTube watchers, instant messaging, website surfers, habitual Facebook users, and so many of the internet services, [19]. To support this statement, [20] reported that the present generation of youths are advancing because of the technology that surrounded them right from birth. Prenksy [21] affirmed this generation as technology guru family of Information Communication Technology (ICT) who are surrounded by video games, computer systems of highest capacity and speed, web cams, digital music, cell phones, digital toys and tools and many more. The author argues that the present day younger children and youths are more competent in using technology because of multitasking, [21]

[22] discovered that among the present university students, there are those that belong to the Net Generation but have inadequate knowledge of technology for learning and socialization. [23] Confirmed that 
students that have rapid switching attitude in using social media exhibit poorer learning behavior and poor performance of tasks.

\section{Technology, social media and students' academic work}

Many scholars have carried out general studies of web technology impact on academic achievement of students. The progressive and destructive impacts of technology on achievement were documented. Researchers like [24] examined the effect of technology on children's early stage learning. The authors discovered a positive impact of technology on learning but seriously advised parents to watch the activities of their wards when using Internet technology. Parents were further advised to direct their wards to sites that will assist them in their academic works. Some other researchers however, discovered that there is no relationship between the use of computers (social media) and students' academic achievement. Hunley et al. [25] carried out a study that proved that the time spent on the computers at home affects the Grade Point Average (GPA) of students' result. Also, [26] observed that Facebook usage affects the GPA academic result of social media users. On the other hand [27], in his own study asserted that Facebook users (social media users) were observed to have lower GPAs than average. However, more research is needed to establish the nature and direction of the relationship between academic work and exposure to social media networks. Flad [16] carried out a study which concluded that $32 \%$ out of $35 \%$ of the students that use social media have poor results in their academic work mainly because most of them left their assignments and home works uncompleted. The researcher concluded that, social media is good for students to socialize with their friends but it has a negative impact on academic work.

\section{Uses of social media:}

To set up profiles and get connected with people

To Build up and preserve popularity [28]

To keep in touch or maintain relationships with classmates, friends and relations

To upload pictures for friends to see

Many schools use social media sites to promote education, update students' assignments and assist those that are slow in understanding some topics in the class, [29]. The objective of the study is to investigate the attitude of students towards using social media tools during formal classes and library session and also to estimate the time spent by students on social media thereby evaluating its affects on academic work.

\section{Research Methodology.}

The postgraduate students were randomly selected from the various colleges. The researcher obtained data in the form of both quantitative and qualitative responses from these students. The questionnaire contained 18 questions which addressed the subject matter of the research. There were 120 questionnaires distributed to the randomly selected postgraduate students physically by the researcher. At the end of distribution, 106 completed questionnaires were collected within three weeks which is $96 \%$ response rate. Fourteen (14) out of the 106 respondents were invalid, leaving 92 which is $88 \%$ response rate.

The distribution modality employed enabled the researcher to be available to explain anything the respondents could not understand, ensure no one responds to the questionnaire more than once and to increase response rate. Another important feature of the design is the short interview time. The interview took a minimum of 5minutes to be responded to while the questionnaire took 2-3minutes to complete. The only problem with this method of distributing questionnaires according[10] is that it requires extra time and added effort. Although It is true that questionnaires can be more easily distributed through electronic mails or interviews conducted through a telephone conversation, this researcher preferred the face-to-face approach, so that the interviewee response will not be influenced by others where the students are to be called together at the same place for the interview.

Both instruments (questionnaire and semi- structured interview) were adopted to measure attitude of students towards using social media in the formal class; the social media they normally use; the duration of time spent on social media; as well as its usefulness and effect on academic work and social behaviour. The postgraduate students of Salford University selected as respondents for this study were aged at least 20years. The students' personal details were not indicated since these were known not to have much effect on the study.

\section{Research Questions (RQ)}

The following are the research questions formulated to guide this investigation:

RQ1: Is social media increasingly being used by students of Salford University during formal classes and library session?

RQ2: Does students' use of social media during formal class and library have any negative impact on their academic work?

RQ3: Are there ways to control the use of social media during formal class and library by students? 
Mixed (qualitative and quantitative) method of data collection was employed for this research. The questionnaire was administered on one hundred and twenty randomly sampled postgraduate students in Salford University who have social media account. While randomly selected six students who has social media account were interviewed.

III. Results and Discussion

Impact of Social Media Usage on Students' Academic studies

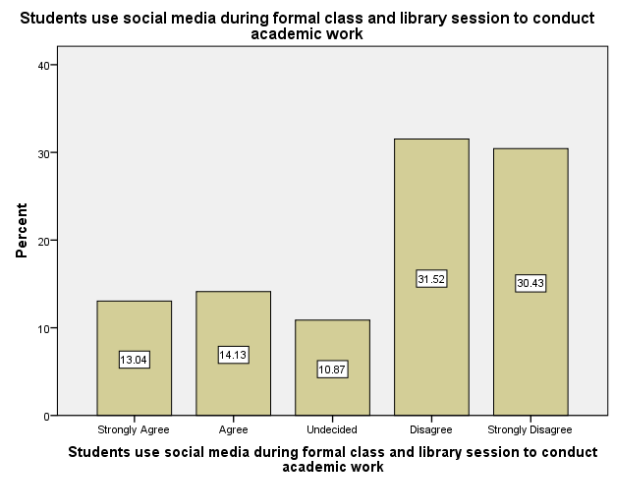

Figure 1: For academic work

Figure 1 above shows $13.04 \%$ of the respondents strongly agreed that students use social media during formal class and Library session to conduct academic work, $14.13 \%$ agreed, $10.87 \%$ were undecided, $31.52 \%$ disagreed while $30.43 \%$ strongly disagreed.

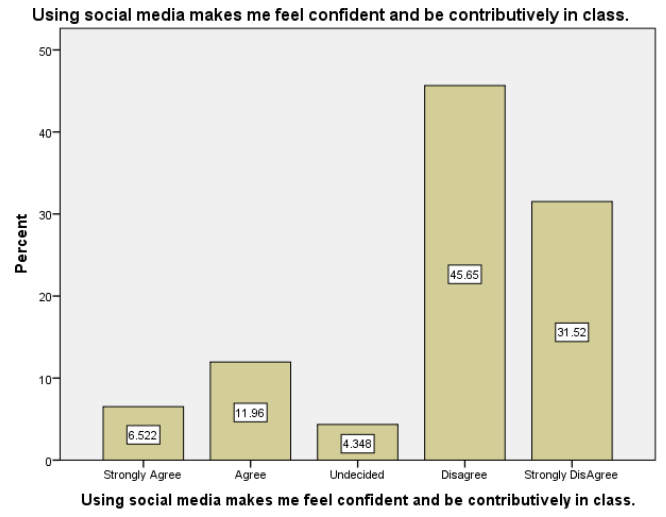

Figure 2: Class work contribution

Figure 2 above, shows $6.52 \%$ of the respondents strongly agreed that using social media makes students feel confident and contributively in the class; $11.96 \%$ agreed, $4.35 \%$ were undecided, $45.65 \%$ disagreed while $31.53 \%$ strongly disagree.

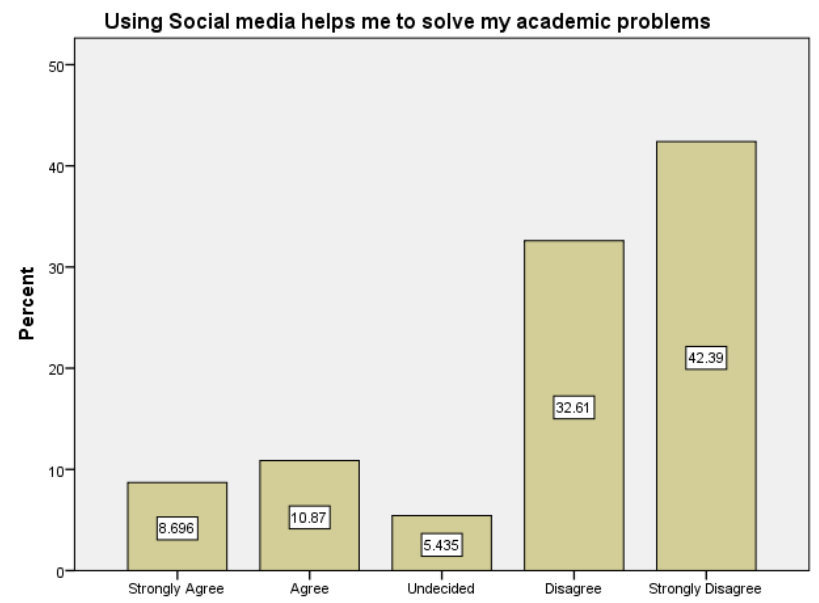

Using Social media helps me to solve my academic problems

Figure 3: Solving academic problem 
Figure 3 above, indicates $8.70 \%$ of respondents strongly agreed that using social media helps students solve their academic problem, $10.87 \%$ agreed, $5.44 \%$ were undecided, $32.61 \%$ disagreed while $42.39 \%$ strongly disagreed

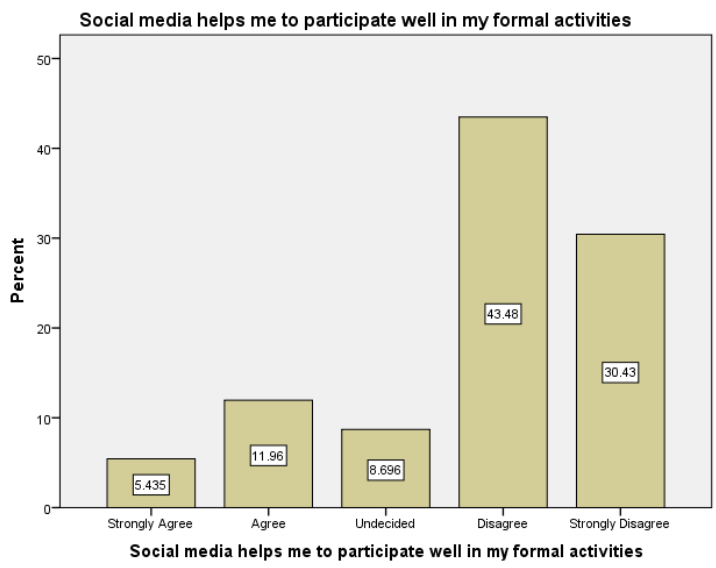

Figure 4: Formal activities

The results shown in figure 18 above, indicates that $5.44 \%$ of respondents strongly agreed that using social media helps students participate very well in the formal activities; $11.96 \%$ agreed, $8.70 \%$ were undecided, $43.49 \%$ disagree, $30.43 \%$ strongly disagree.

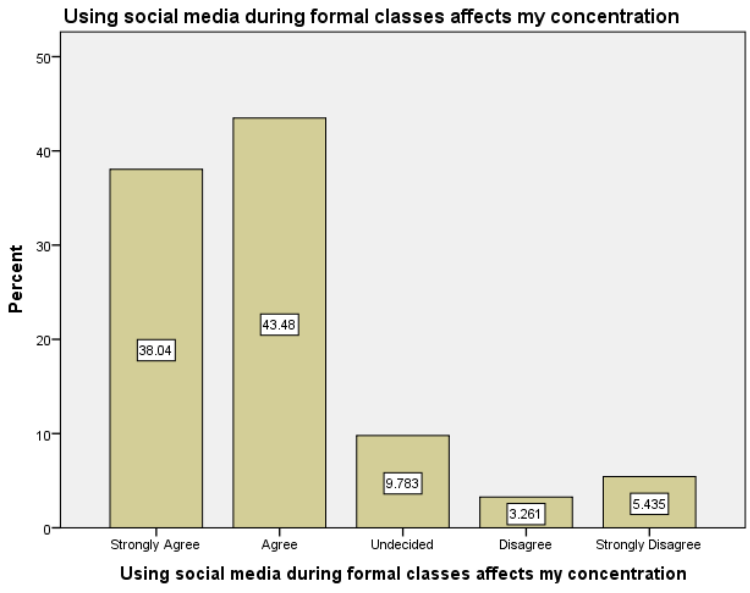

Figure 5: Affects students' concentration

Results in figure 19 above, show that $38.04 \%$ of respondents strongly agreed that students using social media during formal class affect their academic concentration; $38.04 \%$ strongly agreed, $43.48 \%$ agreed, $9.78 \%$ were undecided, $3.26 \%$ disagree and $5.44 \%$ strongly disagree.

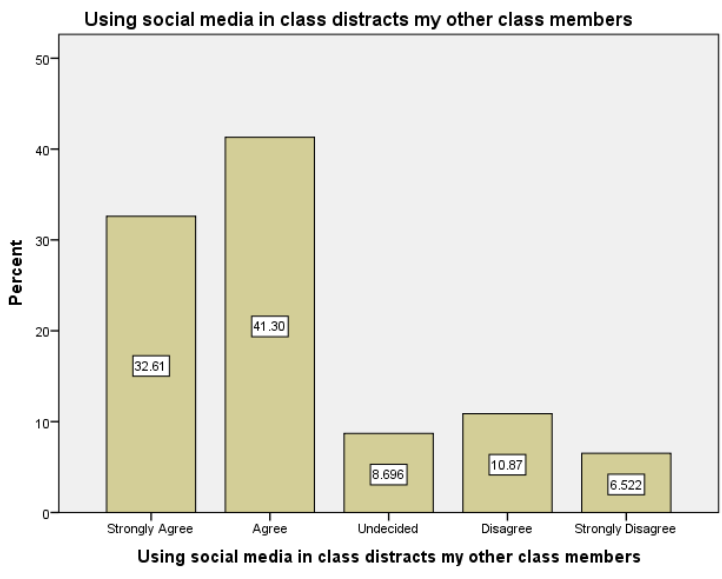

Figure 6: Causes distraction 
Figure 6 , indicates that $32.61 \%$ of respondents strongly agreed that using social media in the class distracts other class members, $41.30 \%$ agreed, $8.70 \%$ were undecided, $10.87 \%$ disagreed while $6.52 \%$ strongly disagreed.

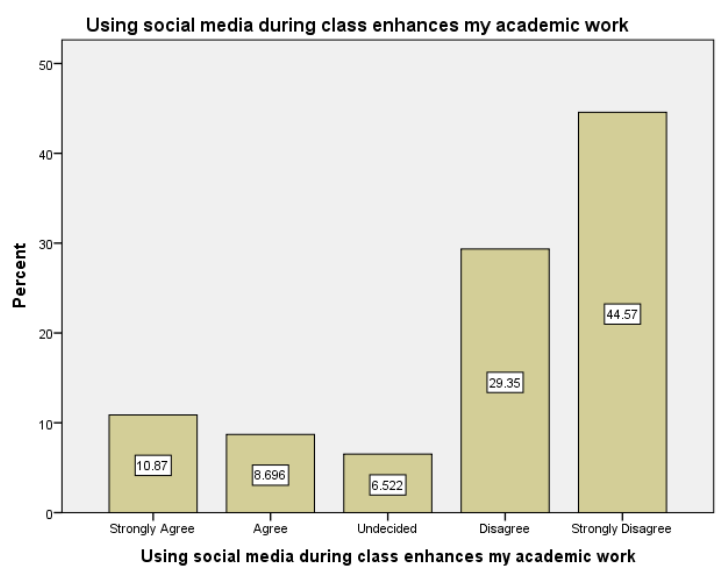

Figure 7: Academic enhancement

Results shown in figure 7 above indicate that $10.87 \%$ of respondents strongly agreed that using social media during class enhances their academic work, $8.97 \%$ agreed, $6.52 \%$ were undecided, $29.35 \%$ disagreed while $44.57 \%$ strongly disagreed.

\section{Conclusion}

The study has shown that social media affects students performance during academic and library session. It therefore suggest that University social media policy must be made mandatory for every institution and remain implemented since findings from this study shows that academic work is negatively affected.

Software developers should create software that could be used to control social media usage in the campus so that students will not lose their primary aim of being in the University.

\section{References}

[1] G. Lewis.,L, Abigail and B Steven [2007]. Social Networking Technology: Place and Identity in Mediated Communities. Journal of Community \& Applied Social Psychology. Vol. 17 pp.463-476 DOI: 10.1002/casp.939

B.Greenwood, [2008]. MySpace, Facebook, Google integrate data portability. Information Today 25 (6): 27

[3] T. Anderson, and J, Dron, [2007].Collective Networks and Groups in Social Software for E-learning.EditLib education and Information Technology Digital Library

[4] D Boyd, and J. Heer, [2006]. Profiles as conversation: networked identity performance on friendster. Proceedings of Thirty-Ninth Hawai'i International Conference on System Sciences. Los Alamitos, CA: IEEE Press.

[5] S Bake [2009]. Why Twitter matters. Businessweek.com. Accessed 05/08/2012 http://www.businessweek.com/technology/content/may2008/tc20080514_269697.htm

[6] M. Thelwall, [2009]. Social Network sites: Users and uses. Advances in Computers.76:. 23-26

[7] J. Cassidy, [2006]. Me Media: how hanging out on the internet became big business. The New Yorker, 82(13), 50

[8] J. Zywica, and J. Danowski, [2008]. The faces of facebookers: investigating social enhancement and social compensation hypotheses; predicting Facebook and offline popularity from sociability and self-esteem, and mapping the meanings of popularity with semantic networks. Journal of Computer-Mediated Communication 14, 1:1-34

[9] T. A Pempek, Y.A Yermolayeva, and S.L Calvert, [2009]. College students' social networking experiences on Facebook. Journal of Applied Developmental Psychology, 30, 227-238.

[10] Facebook Statistics.[2011]. Statistics | Facebook.Press Room. Retrieved from http://www.facebook.com/press/info.php?statistics on $05 / 08 / 2012$

[11] D. Wilkinson, and M. Thelwall . [2010].Social network site changes over time: The case of MySpace; Journal of the American Society for Information Science and Technology 61, 11:, 2311-2323,

[12] Al-Ammari, J. (2004). Benefits and barriers to implementing computer use in Qatari Elementary School as perceived by female teachers: an exploratory study. (Unpublished PhD Thesis) Ohio University

[13] J.Bonds-Raacke, and J Raacke, [2008]. MySpace and facebook: Applying the uses and gratifications theory to exploring friendnetworking sites. CyberPsychology andBehavior, 11, 169-174.

[14] R.W. Lent, M, Taveira, H.B. do Céu.,Sheu, and D. Singley, [2009] Social cognitive predictors of academic adjustment and life satisfaction in Portuguese college students: A longitudinal analysis. Journal of Vocational Behavior74: 190-198

[15] K. Flad, [2010]. The Influence of Social Networking Participation on Student Academic Performance across Gender Lines, Counsellor Education Master's thesis.Paper 31. Accessed on 31/07/2012 from http://digitalcommons.brockport.edu/edc_theses/31

[16] J.I Kord, [2008]. Understanding the Facebook generation: a study of the relationship between online social networking and academic and social integration and intentions to enrol: (Unpublished PhD dissertation) University of Kansas Retrieved 29/07/2012 from http://proquest.umi.com.eserv.uum.edu.my/pqdweb?index

[17] L.D Rosen, [2007]. Me. Myspace and I: Parenting the net generation Palgrave Macmillan, NewYork. Chicago

[18] W. Veen, and B. Vrakking, [2006], Homo Zappiens: Growing up in a digital Age Network Continuum Education, London.

[19] Beastall [2008].Enchanting a disenchanted child: Revolutionizing the means of education using information and communication technology and e-learning.British Journal of Sociology of Education, 27 (1):. 97-110

[20] M. Preksy, [2001]. Digital game-based learning ACM Computers in Entertainment, 1 (1):. 1-4 
[21] A Margaryan, and A, Littlejohn, [2008]. Are digital natives a myth or reality? Students' use of technologies for learning.available online at

http://www.academy.gcal.ac.uk/anoush/documents/DigitalNativesMythOrReality-MargaryanAndLittlejohn-draft-111208.pdf.

[22] American Psychological Association (2006).Multitasking $=$ Switching Costs.Available at http://www.apa.org/research/action/multitask.aspx.

[23] B,Tynes, [2009]. Internet safety gone wild? Sacrificing the educational and Psychosocial benefits of online social environments. Journal of Adolescent Research, 22, 575-584.

[24] S.A. Hunley, J.H Evans, M, Delgado-Hachey, J.R Krise, and T.C Schell [2005].Adolescent computer use and academic achievement Adolescence, 40: 307-318

[25] P.A Kirshner, and A.C.Karpinski, [2010.] Facebook and Academic Performance, Online Interactivity: Role of Technology in Behaviour Change. Computers in Human Behaviour, 26, 6: 1237-1245

[26] M.R VandenBoogart,[2006]. Uncovering the social impacts of Facebook on a college campus.Unpublished Master's Thesis.Kansas State University

[27] A. Sibak, [2009]. Constructing the self through the photo selection- Visual impression management on social networking websites.Journal of Psychological Researchon Cyberspace, $3(1) \quad 1-6 . \quad$ Retrieved from: http://www.cyberpsychology.eu/view.php?cisloclanku=2009061501\&article =1

[28] D.Boyd, and N.B Ellison, [2007]. Social Network Sites: Definition, History and Scholarship. Journal of Computer-Mediated Communication 13 1: 210-230. 